\title{
DECONSTRUCTING DESIGN TO FACILITATE ITS RESEARCH WITHIN PUBLIC SERVICE ORGANISATIONS
}

\author{
Mateusz Lewandowski*
}

\begin{abstract}
Background. Design in public service organisations is an important context, possibly influencing many aspects of public management. Yet it has not been well included in the main research stream as a variable, mostly due to elusive understanding of the phenomenon and its weak operationalisation.

Research aims. This paper aims to further the understanding of design within Public Service Organisations (PSOs), in order to propose the main dimensions for measuring design within PSOs.

Methodology. This study uses a literature review and deconstruction based on a narrative analysis. Literature has been hand-picked according to snowball effect logic.

Key findings. The obtained results of deconstruction allowed for proposing a consistent and comprehensive framework of design within PSOs. It facilitates research by giving the ground for developing concrete measures.
\end{abstract}

Keywords: public service organisation, service design, deconstruction, design framework, measuring design.

Acknowledgment: This paper presents the research results of the project "Zarzadzanie efektywnością i jakością informacji w jednostkach samorządu lokalnego w Polsce”, funded by the National Science Centre, Poland, Project No. 2016/21/D/HS4/00716.

\section{INTRODUCTION}

Many local governments in Poland and their organisational units experience difficulties in monitoring and controlling the execution of public tasks and delivery of public services (Fundacja Rozwoju

\footnotetext{
* Jagiellonian University in Kraków. E-mail: mateusz.lewandowski@uj.edu.pl
} 
Demokracji Lokalnej, 2013; Gawroński, 2010). One reason for this state of affairs may be the low quality of performance information and inadequacy of the features of the information to the needs of local governments. Poor quality of information is likely due to the lack or limited organisational preparation of local governments to implement and use performance management systems. Such organisational readiness has been described and operationalised in the literature (eg. Van Dooren et al., 2015; Haber \& Szałaj, 2010; Niven, 2003). Yet, research has hardly recognised this relationship as embedded within a larger context of strong trends observed in the public sector, such as innovation and co-production (Hughes et al., 2011; Lewandowski \& Kożuch, 2017; Mulgan \& Albury, 2002; Osborne \& Strokosch, 2013). Within this notion, public service design emerges as a relevant and potentially influential factor allowing to incorporate citizen-customer needs (Lewandowski, 2017; Osborne et al., 2016; PDR, 2013; Thoelen et al., 2015). Future research must incorporate it as a variable, yet service design in general struggles with definitional problems (Saco \& Goncalves, 2008; Whicher et al., 2013), hindering its operationalisation. Such scale as a design ladder (Design Commission, 2013, p. 28) is far too simple to give knowledge on design within the organisation. Other research streams investigate design effects (Lørlie et al., 2008), but those conceptual frameworks are inappropriate to measure organisations' capabilities in designing. In turn, Hertenstein et al. (2013) used a survey examining how good design is defined by industrial design managers. This study unveiled 14 themes related to customer experience of which 10 focused on the company. Although valuable for its in-depth insights into design as a quality feature, it helps to comprehend a rather narrow aspect of the complexity of design, and pertains directly to the private sector organisations.

Much better understanding of the design phenomenon is needed to facilitate research of design capabilities of public service organisations. Thus, this study employs a literature review and deconstruction to further the understanding of design within Public Service Organisations (PSOs), and to propose the main dimensions for measuring design within PSOs.

The paper is organised as follows. First, the design of this study is explained and methodological remarks are outlined. Then, design definitions and components are presented. Next, the constituting 
elements of design are rearranged, and the proposition of measuring dimensions are derived from the literature. In the end, the reconstructed framework is presented and discussed.

\section{DESIGN OF THE STUDY AND METHODOLOGICAL REMARKS}

This study is located on the boarder of conceptualisation of design as a phenomenon, and methodological issues related to measuring this phenomenon. The literature review has been hand-picked, partly by following the snowball effect of familiarising with the body of literature devoted to particular design aspects, which Gloppen (2009) differentiated as the components of service design: such as management and leadership, attitude, thinking, and skills. This allowed for identifying several constructs describing the phenomenon of design relevant for Public Service Organisations (PSOs). Next the key construct has been identified among the analysed group, according to its relevancy to explain the essence of service design (Table 1).

Table 1. The constructs used to deconstruct design in PSOs

\begin{tabular}{|l|l|l|}
\hline $\begin{array}{c}\text { Type of design } \\
\text { component }\end{array}$ & \multicolumn{1}{|c|}{ Constructs used } & \multicolumn{1}{c|}{ Sources } \\
\hline Main & Design attitude & Bason (2014); Michlewski (2008) \\
\hline \multirow{5}{*}{ Supplemental } & Design skills & Gloppen (2009); Miller and Moultrie (2013) \\
\cline { 2 - 3 } & Definitions & $\begin{array}{l}\text { Gloppen (2009); Hertenstein et al. (2013); } \\
\text { Public Administration Select Committee } \\
\text { (2008); Saco and Goncalves (2008); Thoelen } \\
\text { et al. (2015); Whicher et al. (2013) }\end{array}$ \\
\cline { 2 - 4 } & $\begin{array}{l}\text { Co-design within } \\
\text { co-production }\end{array}$ & Osborne et al. (2016) \\
\cline { 2 - 3 } & Design thinking & $\begin{array}{l}\text { Design Council (2007a, 2007b); IDEO } \\
\text { (2012); PDR (2013); Thoelen et al. (2015) }\end{array}$ \\
\cline { 2 - 4 } & Design-driven approach & Lee and Evans (2012) \\
\cline { 2 - 3 } & $\begin{array}{l}\text { Design management } \\
\text { and leadership }\end{array}$ & $\begin{array}{l}\text { Gloppen (2009); Lee and Evans (2012); } \\
\text { Mozota (2008) }\end{array}$ \\
\hline
\end{tabular}

Source: own elaboration based on the reviewed literature. 
The original papers describing the genuine categories constituting the dimensions of the main construct - design attitude - have been then used for deconstruction employing a narrative analysis (Van Thiel, 2014). It encompassed the utterances of the authors of the papers, and the quoted utterances of interviewed designers, design leaders, and public managers of design projects, presented therein. For each genuine category some real life design manifestations have been identified, analysed, and regrouped to new categories.

From the analysis of the original constructs constituting the design attitude, new components of the design framework have been derived according to the input-process-output scheme. A similar one has been very useful to mitigate the problems of measuring trust (Dietz \& Hartog, 2006), for instance, and has been implicitly applied to explain design thinking in the public sector (Ansell \& Torfing, 2014). Table 2, reflecting

Table 2. The surface levels of the conducted deconstruction

\begin{tabular}{|c|c|c|}
\hline $\begin{array}{l}\text { Michlewski's genuine categories substanti- } \\
\text { ated by designers utterances }\end{array}$ & $\begin{array}{l}\text { Michlewski's } \\
\text { main dimen- } \\
\text { sions of the } \\
\text { design attitude }\end{array}$ & $\begin{array}{l}\text { Reconstructed } \\
\text { design components } \\
\text { within input- } \\
\text {-process-output } \\
\text { framework }\end{array}$ \\
\hline $\begin{array}{l}\text { - Reconciling contradictory commercial objec- } \\
\text { tives } \\
\text { - Bridging approaches, swinging between syn- } \\
\text { thesising and analysing } \\
\text { - Consolidating multiple languages and media }\end{array}$ & $\begin{array}{l}\text { Consolidating } \\
\text { multidimension- } \\
\text { al meanings }\end{array}$ & \multirow{2}{*}{$\begin{array}{l}\text { Design as intellec- } \\
\text { tual and sensorial } \\
\text { endeavour (process) }\end{array}$} \\
\hline $\begin{array}{l}\text { - Visual discourse, visual thinking, creative } \\
\text { dialogue } \\
\text { - Aesthetics, beauty, taste } \\
\text { - Intuition, instinct, tacit knowledge }\end{array}$ & $\begin{array}{l}\text { Engaging } \\
\text { polysensorial } \\
\text { aesthetics }\end{array}$ & \\
\hline $\begin{array}{l}\text { - Creative manifesting } \\
\text { - Rapid prototyping } \\
\text { - Working with tangibles }\end{array}$ & $\begin{array}{l}\text { Creating, bring- } \\
\text { ing to life }\end{array}$ & $\begin{array}{l}\text { Designerly behaviour } \\
\text { (output) }\end{array}$ \\
\hline $\begin{array}{l}\text { - Freedom to think and behave differently } \\
\text { - Allowing oneself not to be 'in control' } \\
\text { - Linear process, detailed planning vs. 'let's see } \\
\text { how it goes' }\end{array}$ & $\begin{array}{l}\text { Embracing dis- } \\
\text { continuity and } \\
\text { open-endedness }\end{array}$ & $\begin{array}{l}\text { Design-oriented } \\
\text { Management (input) }\end{array}$ \\
\hline $\begin{array}{l}\text { - Concentrating on people, human-centeredness } \\
\text { - Sense of commercial purpose }\end{array}$ & \multirow{2}{*}{$\begin{array}{l}\text { Engaging } \\
\text { personal and } \\
\text { commercial } \\
\text { empathy }\end{array}$} & $\begin{array}{l}\text { Design as belief and } \\
\text { intention (process) }\end{array}$ \\
\hline $\begin{array}{l}\text { - Authenticity, playfulness } \\
\text { - Transparency of communication }\end{array}$ & & (not used) \\
\hline
\end{tabular}

Source: own elaboration based on Michlewski, 2008 
the surface level of the conducted analysis, presents the simplified logic behind the undertaken deconstruction. Other reviewed literature, not used for the deconstruction, has been used to support delineation of the new design framework.

\section{UNCOUPLING DESIGN}

The challenge regarding service design research is related to various forms and ways design manifests itself in practice. In particular, literature outlines a few conceptualising directions, such as definitions (Saco \& Goncalves, 2008) and locus within the co-production framework (Osborne et al., 2016), and also several constituting components of service design, such as: attitude, approach, skills, thinking, management, and leadership (Gloppen, 2009; Lee \& Evans, 2012).

\section{Definitions and locus in co-production framework}

Design has been defined in many ways, and there is no consensus about best way of defining it (Saco \& Goncalves, 2008, p. 12; Whicher et al., 2013). Moreover, the definitions appear in several areas. Three key ones have been combined to illustrate the approaches and some of their main nuances, in particular between public sector and industrial design (Table 3).

Regarding public management the newest approach to co-production allocates public service design therein (Osborne et al., 2016). Co-design is defined as a "conscious and voluntary act" of "creating capacity within public service delivery systems" and "improving the design and delivery of a public service" (Osborne et al., 2016, pp. 647-648). This approach highlights the performing side of design. In particular, by involving the service user in the process of improvement of a parcitular service he/she is using or the service as a whole (Osborne et al., 2016). To some extent, the performative nature of design is reflected in the types of the service user contributions to co-production (Alford, 2016). It has been pointed more expresively by Sanders (2002), who argues that co-design means collective "making" (conttrasted to saying and doing). Also others emphasised the applicative virute of design (Barzelay \& Thompson, 2010). 


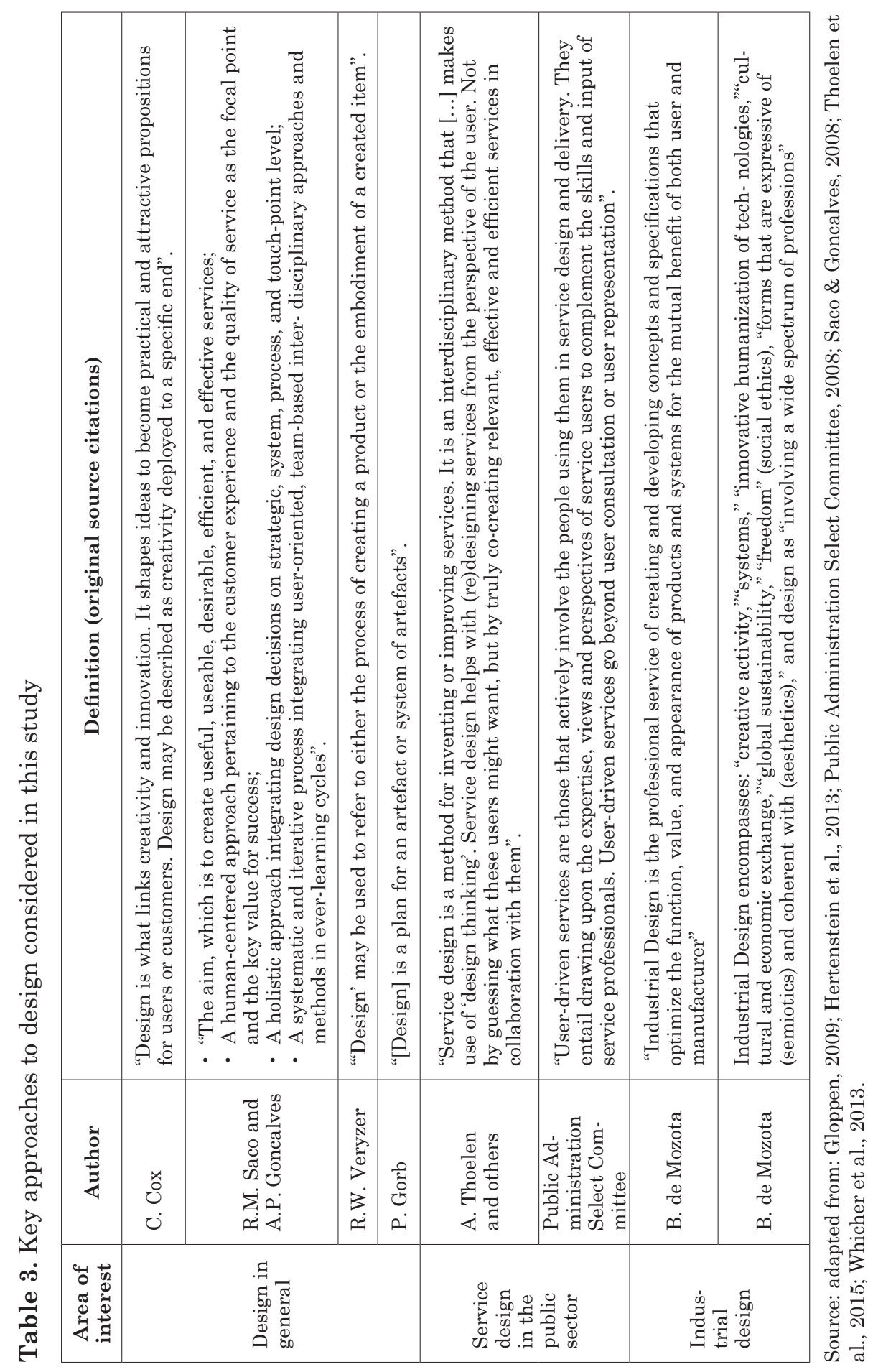




\section{The main components of the design framework}

In the literature there are a few major constructs constituting design. Design attitude is reflected by expectations and orientations one brings to a design project (Boland \& Collopy, 2004, p. 9). It is perceived as a distinct mindset for problem solving and decision making (Michlewski, 2008, p. 374), or a set of certain ways in which public managers address the challenges and opportunities they face (Bason, 2014, p. 216). In particular Michlewski (2008) approached the culture of designers, and distinguished several components. Consolidating multidimensional meanings pertains to involvement in reconciling different, operational objectives of an organisation, and embraces the thinking process encapsulated in an analysis-synthesis loops, which help to achieve a balance between internal cohesion and meeting practical constraints. Engaging polysensorial aesthetics, in turn, is reflected by designers "using aesthetic sense and judgment while interacting with the environment" (Michlewski, 2008, p. 381). Creating, bringing to life is focused on giving tangible forms to thoughts, ideas. Embracing discontinuity and open-endedness describes the designers' willingness to improvise within the ambiguous process, being open for unknown and uncertain outcomes. In turn, engaging personal and commercial empathy means on the one hand an upfront human-centred orientation of designers', based on deep, aesthetic listening and dialogue with service users, and on the other hand adjusting to the commercial or economic requirements.

Similarly, Bason (2014) identified four components of the design attitude of public managers. Questioning assumptions pertains to the situation in which managers constantly question the assumptions underlying their decisions, and are willing to understand what is really going on. Centering on outcomes means that the managers focus on the outcomes, on the intended change in the world they wish to achieve. Stewarding the unknown is when the managers, while governing the collaborative process, are responsible for disturbing and challenging their staff, by moving them from their comfort zones, and allow for uncertainty, lack of definite answers, and also their staff for searching new solutions themselves (for example through various forms of experimentation, trial and error). Finally concretising the future encompasses the managers making and shaping the future state of 
affairs concretely by using models, sketches or other ways, to make proposed solutions visible, or even touchable.

Design thinking has been reflected by the design process. In 2007, the Design Council (2007b) conducted a study to explore its elements, their sequence, and methods used, among other things. It resulted in delineating the 'double diamond' design process model. Therein, there are four distinct phases: discover, define, develop, and deliver. The discovery phase begins with an identification of users' needs facilitating an initial idea or inspiration for the project. The definition stage focuses on interpreting those needs and aligning them with business objectives. The development phase provides design-led solutions for iteration and testing within the organisation. Eventually, in the delivery phase the results are launched after final testing, and project is evaluated (Design Council, 2007a, 2007b). This approach is suggested for public service design (Thoelen et al., 2015), however other sources use different labels or indicate slightly different phases of the design process (IDEO, 2012; PDR, 2013).

Gloppen (2009) argues that designers' skills embrace those typical for designers, such as sketching, design thinking, and several other skills. This notion has been examined in detail by others. For example, Miller and Moultrie (2013) focused on capturing design skills of leading designers. Their research distinguished five design skills, such as: inspiring, imagining, envisioning, designing, and editing. Besides, they pointed a bit less relevant, nevertheless related groups of skills, embracing: cognitive, interpersonal, business, and strategic skills (Miller \& Moultrie, 2013).

The design-driven approach distinguishes four components (Lee \& Evans, 2012). The designerly application comprises "designerly ways to conceptualize and exploit a task in a project and organization" (p. 76). It is based on abductive thinking, challenging constraints, making ideas tangible, and using iterative processes. Design endorsement encompasses "organizational commitments to embed and enhance designerly applications" (p. 76). It may take the form of championing design and investing in its development, or changes of the organisational culture. Collaboration engaging internal and external stakeholders representing various perspectives (engineering, finance, design, and other) is essential to transform designerly applications into concrete solutions. Sometimes designers are deployed across departments, in order to enhance collaboration and reduce "contradictory situations 
between design and other departments" (p. 76). Human resources play a key role, thus staff should be encouraged to understand what design is and how it benefits to the organisation, and design-driven culture should be disseminated to change the employees' mindset (Lee \& Evans, 2012).

Design management and leadership are the last components described. Design management initially in 1960s meant managing relations between a design agency and its clients, yet it evolved ever since, and there is no common understanding what it is, nor agreement how it is different from design project management and design leadership (Mozota, 2008). For example, design management is perceived as "identification and allocation of creative assets within an organization to create strategic, sustainable advantage", a "bridge between design and business", or "effective deployment by line managers of the design resources available to an organisation in the pursuance of its corporate objectives" (Gloppen, 2009). Despite definitional concerns, one remains certain - the way how management, organisation, and leadership influence design is crucial for both, designerly practice and organisations' success (Lee \& Evans, 2012).

\section{RECONSTRUCTING THE DESIGN FOR PSOS}

\section{Design as belief and intention}

As indicated in the previous section, design attitude has been defined in the literature, however it embraces several various components. Revisiting core descriptions of design in the studies of Michlewski (2008) and Bason (2014) allowed to extract smaller components constituting several aspects of design as a belief and intention. Those categories refer to design as an attitude, but in its narrow sense comparing to Michlewski (2008) and Bason (2014).

The first fundamental category of Michlewski (2008) - engaging personal and commercial empathy - comprises human-centeredness, and the sense of commercial purpose. The first one means putting users and their needs as the highest priority, goal, and point of reference. Whatever is being designed, it is always done from a human-centred point of view. The second, however, assumes balancing the first one with commercial aspects which designers must respond to. In the 
public sector, the commercial notion may be replaced by pursuing cost-efficiency. Transparency of communication, and authenticity and playfulness mentioned by Michlewski (2008) are not well justified nor explained. Moreover, they seem to be rather additional, even to the author himself. Centering on the outcomes, outlined by Bason (2014), is a similar category. Its general sense is depicted by human-centeredness, and embraces three manifestations, such as prioritising outcome for users over satisfaction of staff, if they are conflicting, focusing on users experiences expressed by the users themselves, rather than on services, and conviction that managers should see for themselves how users consume services, to get a better understanding of the real situation before deciding what changes should be made and how. Bason's category puts much less emphasis on commercialism, and builds more on responsiveness, which is more accurate for the public sector. Nevertheless, budgetary requirements are crucial for the public sector, so this economic aspect should be represented in the designerly belief. Thereby:

Proposition 1: Operationalisation of design should include design as belief and intention, reflected by: engaging personal and cost empathy, and prioritising outcome responsiveness.

\section{Design as an intellectual and sensorial endeavour}

This component refers to design as a way of thinking, which is tricky for two reasons. Firstly, it may be easily confused with design thinking, which is a broader concept, referring to the methodology as a whole, and embracing also behavioural aspects, such as prototyping and testing. Secondly, design as a style of thinking, or as an intellectual endeavour, uses some of the methods attributed to this methodology, for example reflective and visual thinking (Brand, 2017; Currano et al., 2012). Thirdly, the nature of the design process is iterative, so the way of thinking and the design behaviour stemming from it are constantly being repeated, which blurs the line between intellectual and sensorial effort and its behavioural manifestation. Rosensweig (2011) illustrated well this analytical-research-analytical sequence. Nevertheless, the literature provides several components constituting the core of the design as an intellectual and sensorial endeavour.

Consolidating multidimensional meanings manifests itself in several dimensions (Michlewski, 2008). Such a style of thinking reconciles 
contradictory commercial objectives, puts technical, financial, operational, and emotional pieces together, and also refers to corporate identity related to its mission, buildings, environment, people, behaviour, advertising, among other things (Lojacono \& Zaccai, 2004; Michlewski, 2008). Moreover, as design is an iterative process, such a style of thinking embraces a synthesising and analysing loop, allowing to reconcile internal cohesion and practical constraints as a result (Michlewski, 2008). Engaging polysensorial aesthetics pertains to visualising and thinking through drawing, using various sensorial sources to come up with a solution, and intuition in making aesthetic choices (Cross, 1999; Michlewski, 2008). Questioning assumptions, in turn, is reflected by questioning own understanding of the situation of users, their feelings and needs, questioning the best objective of public provision and what is the best response, and questioning the premises of own managerial decisions (Bason, 2014). In this regard Lee and Evans (2012) talk about "a provocation that encourages organizations to achieve new and novel solutions" which "exemplifies how organizations can adopt such a designerly approach and mindset" (p. 75). Moreover, it is also about experiencing how service users experience their situation, or in other words it means stepping into users shoes, that supports the questioning process and swinging between synthesising and analysing (Bason, 2014). Within this component there are not so many similarities between its constituting elements. Their supplementary relation allows for formulating the following proposition. Thus:

Proposition 2: Operationalisation of design should include design as an intellectual and sensorial endeavour, reflected by: consolidating multidimensional meanings, engaging polysensorial aesthetics, and questioning assumptions.

\section{Design as behaviour}

Design as an intellectual and sensorial endeavour, driven by specific designerly beliefs and intentions, inevitably results in tangible consequences. Design as a behaviour is a direct, visible output of the process.

One of the best ways to approach this output is to see through the lens of "creating, bringing to life" (Michlewski, 2008). Designerly behaviour means that the ideas are creatively manifested in the physical or digital form, and brought to life as rapid prototypes. That sort of tangible results allow to further discuss and debate them with their 
users, and test before delivering the final product, service or solution (Design Council, 2007b; Michlewski, 2008).

Bason (2014), in turn, points to the activity of visualising the abstract idea, problem, or solution, for example through drawings, storyboards, models, etc. as the essence of what he calls concretising the future. In this regard it resembles Michlewski's creative manifestation. However, Bason (2014) within his component of the design attitude - stewarding the unknown - mentions experimenting or doing things differently.

Design is highly collaborative practice. It requires internal cooperation between departments (e.g. engineering, finance) and external cooperation with users, other stakeholders, and also designers if they are not the organisation's members (Ansell \& Torfing, 2014; Lee \& Evans, 2012; Osborne et al., 2016). It is thus interdisciplinary collaboration during the problem exploration and the creation of its solution (Thoelen et al., 2015). Therefore:

Proposition 3: Operationalisation of design should include design as behaviour, reflected by: creating, bringing to life, and interdisciplinary collaboration.

The core components of the design framework reflect the process of design: from mindset, through intellectual endeavour, to behaviour. However, this process is embedded in a larger context - it has its antecedents and consequences. Thus, the design framework should embrace those critical factors which directly concern design and condition its process, and those which appear as the main results of this process.

\section{Design as input}

The first group of factors describes organisational factors conditioning deployment of design. Two types of factors play a key role: human resources, including leaders and their skills, motivation of staff, organisational culture, and managerial support.

Design skills and skill categories for design leaders have been investigated by Miller and Moultrie (2013). Their study outlined five categories of skills which design leaders must have, such as:

1. Design skills (inspire, imagine, envision, design, and edit).

2. Cognitive skills (draw, listen, verbalise, observe, learn, write). 
3. Interpersonal skills (motivate, nurture, persuade, negotiate).

4. Business skills (structure, analyse, synthesise).

5. Strategic skills (identify, plan, connect, translate, manoeuvre).

Moreover, it is being argued that designers have tacit knowledge, which they combine with critical thinking in a design process. Through design education and career development they master such skills as "knowing-in-action' (skilfully acting on something without prior thought) and 'reflecting-in-action' (thinking while one is doing something)" (Rosensweig, 2011, p. 19; Schön, 1983). Additionally, designers must be "brave, a little bit crazy [...] willing to say, why not? Let's do this! Let's take a chance" (Michlewski, 2008, p. 381).

Although design skills are essential, other conditions must occur to enable their exploitation, and to acquire them in the first place. Generally, it is about organisational commitment to developing design, mastering it, investing in it. Some call such a commitment design endorsement, but it in general leads to creating design culture within an organisation (Deserti \& Rizzo, 2014; Lee \& Evans, 2012). It is also suggested, within DDA, that encouraging employees and other stakeholders to understand and appreciate design requires an appropriate human resources (HR) approach (Lee \& Evans, 2012). This approach is derived from values constituting design culture. Other study support the argument that service design shape organisational culture (Hyde \& Davies, 2004).

The second enabling factor is related to embracing discontinuity and open-endedness (Michlewski, 2008). It is delineated within three dimensions. The fist one pertains to deliberate intention of losing control by "engaging in a process that is not predetermined or planned ahead in detail and where outcomes are unknown or uncertain" (p. 380). Within such circumstances managers and staff should be allowing themselves to see how the process goes, to improvise, and not to be afraid of (reasonably) crazy ideas. The latter, lack of such as dismay, means freedom to think and behave differently, almost illogically, and should be attributed to the design culture within the organisation. How managers behave and stimulate their staff pertains to management and leadership. Design-oriented management and leadership comprises also what Bason (2014) distinguished within his category of stewarding the unknown - that managers delegate responsibility to a lower level of managers and staff to develop solutions within a given design project. Managers should be ready to put staff beyond their 
comfort zone in order to get insights into the problem and develop new solutions. Moreover, managers have personal predispositions to handle the unknown and uncertainty, and managers are leading staff through and to the unknown, undefined, uncertain. Such leadership seems to be underpinned by motivating staff and trust in design leaders' hunch (Bason, 2014).

Another dimension of organisational commitment pertains to how design skills are incorporated within the public service organisation. Several forms exist in this regard (Design Commission, 2013, p. 31). In general, design is either embedded within an existing organisational structure, or it is incorporated through or by external bodies. In the first case an organisation employs on a strategic-level a full time staff member to develop design capacity for the whole organisation and its specific service redesign programmes (e.g. Cornwall Council, Helsinki), or creates an internal agency - a service design unit (e.g. Social Innovation Lab Kent, MindLab). There are three typical forms of external bodies providing design services to PSOs or designing the services themselves. Design-led start-up services are a kind of spin off institutions offering specific public services independently, which are formed from the design teams located initially within a traditional public service institution, (e.g. Participle, Good Gym, Care4Care). In turn, brokered interventions appear when specific organisations, such as Design Council, or NESTA for example, broker design work for a public sector body, delivered by a business entity through procurement. Finally, an external agency is an independent entity, like Ideo or ThinkPublic, delivering consultancy mainly for particular projects (Design Commission, 2013, p. 31).

Forming an organisational structure is in fact a managerial competence. Eventually, such organisational commitment is reflected, to some extent, through the scale of design maturity. The first level embraces using design to add cosmetic value through graphic design, while the second one comprises using design, often unknowingly, for improvements at a project level. The third level, in turn, encompasses deliberately using design to introduce important, tactical changes to various programmes. The most advanced fourth level assumes deploying design as a strategic competency to constantly change and develop the organisation (Design Commission, 2013, p. 28). Considering the variety of inputs it is proposed that: 
Proposition 4: Operationalisation of design should include design as input, reflected by: set of skills relevant for design, design culture, and design-oriented management and leadership.

\section{Design as result}

As emphasised in previous subsections design leads to very concrete outcomes. Several benefits may be attributed to design application, relevant for design project, service users, and the organisation itself (Steen \& De Koning, 2011). However, there are two dimensions depicting what design as a result means. Firstly, design as a process ends up with delivering innovation (Ansell \& Torfing, 2014). It has been recognised as design-driven innovation within a specific ecosystem (European Commission, 2013; Whicher, 2016; Whicher et al., 2016). Secondly, the result is perceived as good design, meaning the quality of service or product (Hertenstein et al., 2013). Originally in this study, good design embraces themes related to the customer and the company, but it may be adopted to the public service organisations (PSOs), too. Customer, or user, related themes comprise aesthetics, functionality, experience (or awareness), and emotional bond. Company or PSO related themes encompass business profits or results, brand, ethical and environmental appropriateness, and doing something innovative, creative or differentiated (Hertenstein et al., 2013).

Proposition 5: Operationalisation of design should include design as result, reflected by design driven innovation and the quality features defining good design.

\section{DISCUSSION AND CONCLUSIONS}

The comprehensive framework of design should capture the relations between its main components, because design is a dynamic process (Rosensweig, 2011).This process has been described in the literature from the perspective of a practical guide, and consists of several phases, like in the well-recognised double diamond diagram (Design Council, 2007a), or as a sequence of analysing, researching, and analysing (Rosensweig, 2011). Conducted deconstruction allows for proposing a slightly different view. The process comprises intellectual and sensorial endeavour, driven by certain beliefs and intentions. The whole process is contingent on design input. In turn, the undertaken design 
endeavour evokes designerly behaviour, which results in delivering innovation and a quality feature labelled as good design. It has been illustrated in Figure 1 below.

\begin{tabular}{|c|c|c|c|c|}
\hline Input & & oces & Output & Outcome \\
\hline $\begin{array}{l}\text { Design as input } \\
\text { - Design skills } \\
\text { - Design culture } \\
\text { - Design-oriented } \\
\text { management } \\
\text { and leadership }\end{array}$ & $\begin{array}{l}\text { Design as belief } \\
\text { and intention } \\
\text { - Engaging } \\
\text { personal and } \\
\text { cost empathy } \\
\text { - Prioritising } \\
\text { outcome } \\
\text { responsiveness }\end{array}$ & $\begin{array}{l}\text { Design as intellectual } \\
\text { and sensorial } \\
\text { endeavour } \\
\text { - Consolidating } \\
\text { multidimensional } \\
\text { meanings } \\
\text { - Engaging } \\
\text { polysensorial } \\
\text { aesthetics } \\
\text { - Questioning } \\
\text { assumptions }\end{array}$ & $\begin{array}{l}\text { Design as } \\
\text { behaviour } \\
\text { - Creating, } \\
\text { bringing to life } \\
\text { - Interdisciplinary } \\
\text { collaboration }\end{array}$ & $\begin{array}{l}\text { Design as } \\
\text { result } \\
\text { - Design-driven } \\
\text { Innovation } \\
\text { - Good design } \\
\text { as a quality } \\
\text { features }\end{array}$ \\
\hline
\end{tabular}

Figure 1. The design framework based on input-process-output logics

Source: own elaboration based on conducted deconstruction.

The conducted deconstruction of design allowed not only to regroup and develop its constituting constructs (e.g. engaging polysensorial aesthetics, questioning assumptions), but also pointed that various design manifestations attributed to those constructs exist in real life. Such manifestations should facilitate development of the instrument for measuring design within PSOs.

Additionally, it seems appropriate to refer to the concept of entrepreneurship for disputable similarities. Rosensweig (2011) noticed the potential confusion - "researchers investigating how creative organizations promote creative capabilities to generate value have found that the most successful organizations have "creative entrepreneurs' who build collaboration, exploit knowledge, and enhance relationships in and outside of the organization - evidence of some skill at design thinking". For example, centering on the outcomes (Bason, 2014) is similar to entrepreneurship in terms of pursuing opportunity and risk taking (Boyett, 1996). Yet, the significant difference is that entrepreneurs see the opportunity mainly for themselves, while designers believe an opportunity exist (it is not seen yet), and their attention is focused on the opportunities for service users (Bason, 2014; Zerbinati \& Souitaris, 2005). Moreover, the design process is heavily based on creative techniques (Brand, 2017). 
Neither creativity, nor entrepreneurship, nor other concepts relevant to broaden understanding of design, have been incorporated in this study. Moreover, here design has been perceived as general concept, yet it has many specific applications in such fields as architecture, arts, user emotions, user interfaces etc. The differences between those fields of application might indicate some distinctive features of design, relevant only for each of the particular fields.

The future research could focus on those limitations. Another direction is developing design capability measures which would allow to make comparisons, for example with management capabilities, and to test interrelations with various other variables and constructs, such as quality of performance information. However, particular design manifestations must be verified against their overlap in order to develop a coherent instrument.

This paper contributes to the theory by providing a more comprehensive and coherent understanding of design, and indicates the main dimensions for measuring design in public service organisations and other organisations as well.

\section{REFERENCES}

Alford, J. (2016). Co-Production, Interdependence and Publicness: Extending public service-dominant logic. Public Management Review, 18(5), 673-691.

Ansell, C. \& Torfing, J. (2014). Collaboration and design. New tools for public innovation. In: C. Ansell \& J. Torfing (eds.), Public Innovation Through Collaboration and Design. London-New York: Routledge, 1-18.

Barzelay, M. \& Thompson, F. (2010). Back to the future: Making public administration a design science. Public Administration Review, 70, S295-S297.

Bason, C. (2014). Design attitude as an innovation catalyst. In: C. Ansell \& J. Torfing (eds.), Public Innovation Through Collaboration and Design. London-New York: Routledge, 209-228.

Boland, R. \& Collopy, F. (eds.) (2004). Managing as Designing. Stanford University Press.

Boyett, I. (1996). The public sector entrepreneur - a definition. International Journal of Public Sector Management, 9(2), 36-51.

Brand, W. (2017). Visual Thinking. Amsterdam: BIS Publishers.

Cross, N. (1999). Natural intelligence in design. Design Studies, 20(1), 25-39.

Currano, R., Steinert, M. \& Leifer, L. (2012). Design Loupes: A Bifocal Study to Improve the Management of Engineering Design Innovation by Co-evaluation 
of the Design Process and Information Sharing Activity. In: H. Plattner, C. Meinel \& L. Leifer (eds.), Design Thinking Research. Studying Co-Creation in Practice. Berlin-Heidelberg: Springer-Verlag, 36, 89-105.

Deserti, A. \& Rizzo, F. (2014). Design and organizational change in the public sector. Design Management Journal, 9(1), 85-97.

Design Commission (2013). Restarting Britain 2: Design and Public Services.

Design Council (2007a). A study of the design process. London: Design Council.

Design Council (2007b). Eleven Lessons: Managing Design in Eleven Global Companies Desk Research Report. London.

Dietz, G. \& Hartog, D. (2006). Measuring trust inside organisations. Personnel Review, 35(5), 557-588.

European Commission (2013). Implementing an Action Plan for Design-Driven Innovation, 1-12. http://ec.europa.eu/enterprise/policies/innovation/files/ design/design-swd-2013-380_en.pdf (access: 25.02.2017).

Ferrari, P.A. \& Manzi, G. (2014). Citizens evaluate public services: a critical overview of statistical methods for analysing user satisfaction. Journal of Economic Policy Reform, 17(3), 236-252.

Fundacja Rozwoju Demokracji Lokalnej (2013). Zarzqdzanie strategiczne w samorzadzie lokalnym. Wnioski i rekomendacje ptynace z debaty eksperckiej zorganizowanej przez Fundację Rozwoju Demokracji Lokalnej. Fundacja Rozwoju Demokracji Lokalnej. http://www.frdl.org.pl/pliki/frdl/zarzadzanie\%20strategiczne/ Raport_z_debaty.pdf (access: 20.02.2017).

Gawroński, H. (2010). Zarzadzanie strategiczne w samorzadach lokalnych. Warszawa: Wolters Kluwer Polska.

Gloppen, J. (2009). Perspectives on design leadership and design thinking and how they relate to European service industries. Design Management Journal, 4(1), 33-47.

Haber, A. \& Szałaj, M. (eds.) (2010). Ewaluacja w strategicznym zarzadzaniu publicznym. Warszawa: Polska Agencja Rozwoju Przedsiębiorczości.

Hertenstein, J.H., Platt, M.B. \& Veryzer, R.W. (2013). What Is "Good Design"?: An Investigation of the Complexity and Structure of Design. Design Management Journal, 8(1), 8-21.

Hughes, A., Moore, K. \& Kataria, N. (2011). Innovation in Public Sector Organisations: A Pilot Survey for Measuring Innovation across the Public Sector. London: NESTA (March).

Hyde, P. \& Davies, H.T.O. (2004). Service design, culture and performance: Collusion and co-production in health care. Human Relations, 57(11), 1407-1426, http://doi.org/10.1177/0018726704049415 (access: 15.02.2017).

IDEO (2012). Human Cente Design Toolkit. 
Lee, Y. \& Evans, M. (2012). What drives organisations to employ design-driven approaches? A study of fast moving consumer goods brand development. Design Management Journal, 74-88.

Lewandowski, M. (2017). Public organizations and business model innovation: The role of public service design. In: M. Lewandowski \& B. Kożuch (eds.), Public Sector Entrepreneurship and the Integration of Innovative Business Models. Hershey, PA: IGI Global, 47-72.

Lewandowski, M. \& Kożuch, B. (eds.) (2017). Public Sector Entrepreneurship and the Integration of Innovative Business Models. Hershey, PA: IGI Global.

Lojacono, G. \& Zaccai, G. (2004). The Evolution of the Design-Inspired Enterprise. MIT Sloan Management Review, 44(4), 75-79.

Løvlie, L., Downs, C. \& Reason, B. (2008). Bottom-line Experiences: Measuring the Value of Design in Service Bottom-line Experiences: Measuring the Value of Design in Service. Design Management Review, 19(1), 73-79.

Michlewski, K. (2008). Uncovering design attitude: Inside the culture of designers. Organization Studies, 29(3), 373-392.

Miller, K. \& Moultrie, J. (2013). Understanding the skills of design leaders. Design Management Journal, 8(1), 35-51.

Mozota, B.B. de. (2008). A theoretical model for design in management science. Design Management Journal, 3(1), 30-37.

Mulgan, G. \& Albury, D. (2002). Innovation in the public sector. Framework, 16 (October), 1998-2002.

Niven, P.R. (2003). Balanced Scorecard Step-by-step for Government and Nonprofit Agencies. Hoboken, N.J.: Wiley.

Osborne, S.P., Radnor, Z. \& Strokosch, K. (2016). Co-production and the co-creation of value in public services: A suitable case for treatment? Public Management Review, 18(5), 639-653.

Osborne, S.P. \& Strokosch, K. (2013). It takes two to tango? Understanding the co-production of public services by integrating the services management and public administration perspectives. British Journal of Management, 24(S3).

PDR (2013). Designing Effective Public Services: A practical Guide for Public Service Managers.

Public Administration Select Committee (2008). User Involvement in Public Services. Sixth Report of Session 2007-08.

Rosensweig, R.R. (2011). More than heroics: building design as a dynamic capability. Design Management Journal, 6, 16-26.

Saco, R.M. \& Goncalves, A.P. (2008). Service design: An appraisal. Design Management Review, 19(1), 10-19. 
Sanders, E.B.E. (2002). From user-centered to participatory design approaches. In: J. Frascara (ed.), Design and the Social Sciences Making Connections. London: Taylor \& Francis Books Limited, 1-8.

Schön, D.A. (1983). The Reflective Practitioner: How Professionals Think in Action. New York: Basic Books.

Steen, M. \& De Koning, N. (2011). Benefits of co-design in service design projects Marc. International Journal of Design, 5(2), 53-60.

Thoelen, A., Cleeren, S., Denis, A., Peters, K., Van Ael, K. \& Willems, H. (2015). Public Service Design. A Guide for the Application of Service Design in Public Organisations. Brussels.

Van Dooren, W., Bouckaert, G. \& Halligan, J. (2015). Performance Management in the Public Sector (2nd ed.). London-New York: Routledge.

Van Thiel, S. (2014). Research Methods in Public Administration and Public Management. London-New York: Routledge.

Whicher, A. (2016). Benchmarking Design for Innovation Policy in Europe. Doctoral Dissertation at Cardiff Metropolitan University. Cardiff. https://repository. cardiffmet.ac.uk/handle/10369/7999 (access: 1.03.2017).

Whicher, A., Swiatek, P. \& Cawood, G. (2013). An overview of service design for the private and public sectors. See Platform, August.

Whicher, A., Swiatek, P. \& Thurston, P. (2016). Trends in design and government in Europe. Design Management Review, 27(1), 44-50.

Zerbinati, S. \& Souitaris, V. (2005). Entrepreneurship in the public sector: A framework of analysis in European local governments. Entrepreneurship \& Regional Development, 17(1), 43-64. 